\title{
Patterns of Late Cenozoic exhumation deduced from apatite and zircon U-He ages from Fiordland, New Zealand
}

\author{
M. A. House \\ Division of Geological and Planetary Sciences, California Institute of Technology, Pasadena, California 91125, USA \\ Now at Natural Sciences Division, Pasadena City College, 1570 East Colorado Boulevard, Building E, Room 210, \\ Pasadena, California 91106, USA (mahouse@pasadena.edu)
}

M. Gurnis

Division of Geological and Planetary Sciences, California Institute of Technology, Pasadena, California 91125, USA

\author{
R. Sutherland \\ IGNS Ltd., Private Bag 30368, Lower Hutt, New Zealand
}

\author{
P. J. J. Kamp \\ Department of Earth Sciences, University of Waikato, Hamilton 2001, New Zealand
}

[1] New apatite and zircon (U-Th)/He ages from the Fiordland region of New Zealand's South Island expand on earlier results and provide new constraints on patterns of Late Cenozoic exhumation and cooling across this region. Zircon (U-Th)/He cooling ages, in combination with increased density of apatite ages, show that in addition to a gradual northward decrease in cooling ages that was seen during an earlier phase of this study, there is also a trend toward younger cooling ages to the east. Distinct breaks in cooling age patterns on southwestern Fiordland appear to be correlated to the location of previously mapped faults. The northward decrease in ages may reflect asynchronous cooling related to migration in the locus of exhumation driven by subduction initiation, or it may reflect synchronous regional exhumation that exposed different structural levels across Fiordland, or some combination of these effects. In either case, differential exhumation accommodated by major and minor faults that dissect Fiordland basement rocks apparently played an important role in producing the resulting age patterns.

Components: 6546 words, 5 figures, 2 tables.

Keywords: exhumation; Fiordland; helium; New Zealand; subduction; thermochronology.

Index Terms: 1130 Geochronology: Geomorphological geochronology; 1140 Geochronology: Thermochronology; 3060 Marine Geology and Geophysics: Subduction zone processes (1031, 3613, 8170, 8413).

Received 11 March 2005; Revised 8 July 2005; Accepted 21 July 2005; Published 20 September 2005.

House, M. A., M. Gurnis, R. Sutherland, and P. J. J. Kamp (2005), Patterns of Late Cenozoic exhumation deduced from apatite and zircon U-He ages from Fiordland, New Zealand, Geochem. Geophys. Geosyst., 6, Q09013, doi:10.1029/2005GC000968.

\section{Introduction}

[2] Late Cenozoic exhumation of the Fiordland region of New Zealand's South Island temporally coincides with the timing of increased convergence across the adjacent segment of the PacificAustralian plate boundary [House et al., 2002; Walcott, 1998]. Low temperature thermochronometric data (apatite (U-Th)/He and fission track ages) show a more or less continuous northward 


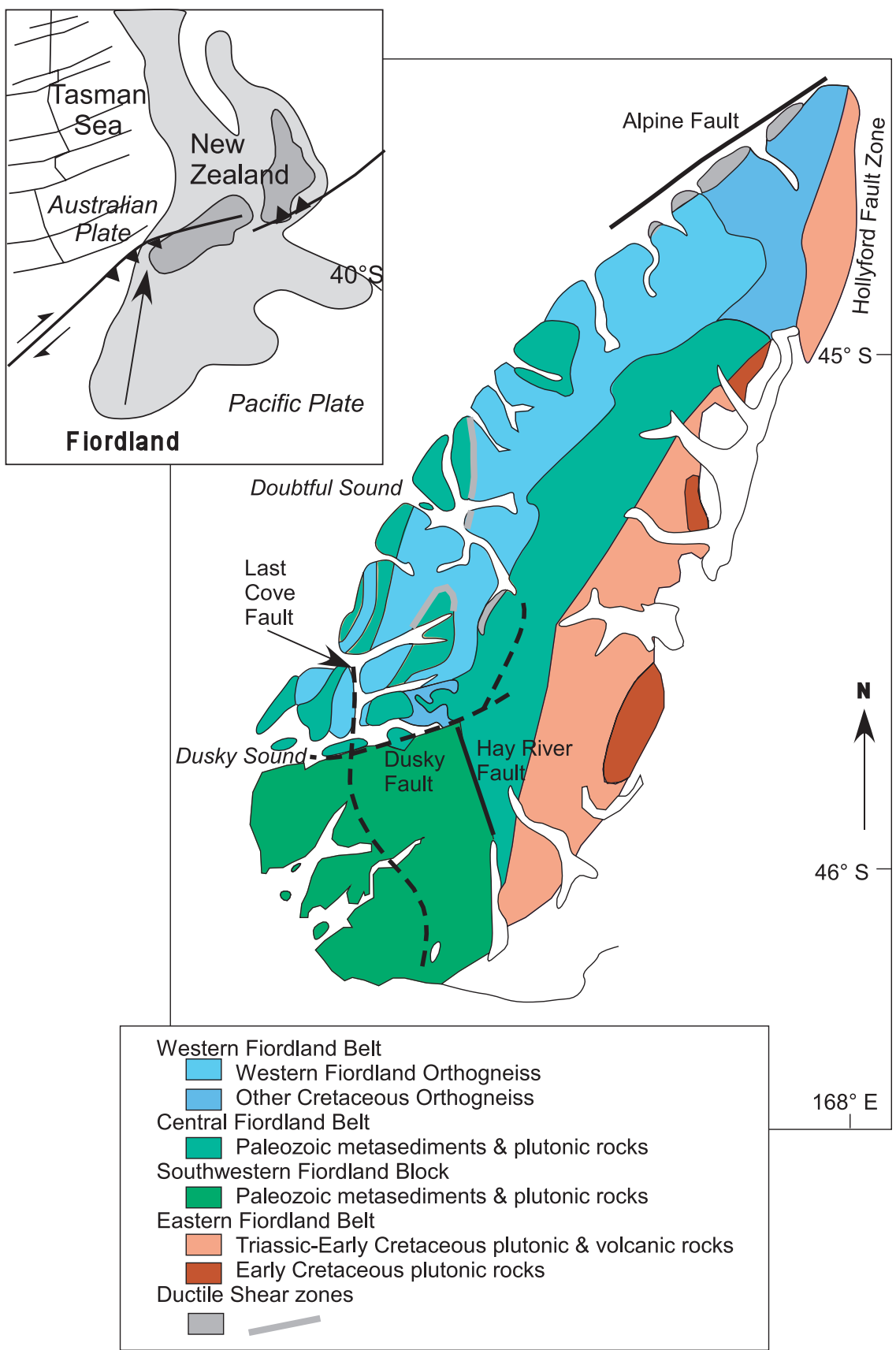

Figure 1. Geologic map and plate setting of Fiordland [Bradshaw, 1990; Muir et al., 1998].

decrease in age that has been interpreted to reflect the coincident migration of the locus of bedrock uplift and exhumation related to subduction initiation offshore to the west [House et al., 2002]. Persistence of a large positive Bouguer gravity anomaly centered on the region of most recent bedrock uplift attests to the isostatic disequilibrium of Fiordland and provides an additional link to subduction initiation as the cause of the exhumation [Toth and Gurnis, 1998].
[3] We report here new apatite and zircon (U-Th)/ He cooling ages from Fiordland that expand the scope of our original study and provide a more complete picture of how Late Cenozoic exhumation is distributed across Fiordland. Our results confirm previously identified patterns of cooling ages, but also indicate that southwest Fiordland has a cooling history that is distinct from that of regions to the north and northeast. Zircon (U-Th)/ He cooling ages-the first from this region-allow us 
to better constrain spatial variations in the timing of the onset of Late Cenozoic exhumation and provide limits on the total amount of exhumation.

\section{Tectonic Setting and Geology of Fiordland}

[4] Fiordland, southwestern South Island, New Zealand, stands as a topographically elevated region situated above the leading edge of the over-riding plate at the highly oblique PacificAustralia nascent subduction zone (Figure 1). The subducting Australian plate is seismically active and imaged as a steeply-dipping high seismic velocity zone to depths of about $150 \mathrm{~km}$ beneath Fiordland [Eberhart-Phillips and Reyners, 2001]. The slab is highly curved in its upper part and the surface trace of the subduction interface lies $\sim 40 \mathrm{~km}$ northwest of the Fiordland coast. Surficial deformation offshore is partitioned into shortening of the Fiordland Basin accretionary wedge, and dextral strike-slip displacement on the Alpine Fault [Barnes et al., 2001]. Shortening of the Pacific plate to the east of the Alpine Fault is distributed across a zone $\sim 250 \mathrm{~km}$ wide in southern South Island that encompasses Fiordland.

[5] A complex zone of faulting in the western Te Anau Basin that continues northward as the Hollyford Fault System [Norris and Turnbull, 1993; Oliver and Coggon, 1979] defines the eastern limit of plutonic and high-grade metamorphic basement rock that underlie Fiordland (Figure 1). North of Dusky Sound, western and central Fiordland contain a wide range of Cretaceous amphibolite and granulite facies metamorphic rocks, including the Western Fiordland Orthogneiss that are juxtaposed with a belt of low grade Triassic-Early Cretaceous metaplutonic and metavolcanic rocks (Eastern Fiordland Belt, Median Tectonic Zone, or Median Batholith) [Bradshaw, 1989, 1990; Clarke et al., 2000; Daczko et al., 2001; Kamp, 1986; Kimbrough et al., 1994; Mortimer et al., 1999; Muir et al., 1998; Oliver and Coggon, 1979; Tulloch, 1983; Ward, 1984].

[6] The metamorphic grade and exposure level of basement rocks decreases significantly in southwestern Fiordland, to the south of the Dusky Fault [Cooper, 1989; Ward, 1984]. Basement rocks south of Dusky Sound can be roughly divided into two terranes: the Fanny terrane on the west consists of low- to medium-grade quartzites and argillites, while the Goodyear terrane on the east is composed of $\sim 350-370 \mathrm{Ma}$ plutonic rocks that intrude amphibolite facies metapelites and metavolcanics [Muir et al., 1998; Tulloch, 1983; Ward, 1984].

[7] Patterns of Cenozoic exhumation of Fiordland have changed since initiation of the AustraliaPacific plate boundary through New Zealand in Eocene time [Ward, 1984; Wood et al., 1996]. A record of the changing paleogeography is partly preserved in remanent adjacent sedimentary basins [Norris and Turnbull, 1993; Turnbull et al., 1993]. Middle and Late Eocene conglomerates are mainly derived from eastern Fiordland and are interpreted as proximal deposits to normal faults. Normal faults with clearly imaged Middle Eocene-Early Oligocene growth strata are imaged by seismic reflection data to the south and east of Fiordland [Norris et al., 1978; Turnbull and Uruski, 1995; Turnbull et al., 1993]. Significant paleogeographic changes in Late Oligocene and Early Miocene times adjacent to Fiordland, combined with evidence for the onset of folding in the Southern Alps, has led previous workers to hypothesize that this is when a change to locally transpressive strike-slip motion occurred and the Alpine Fault initially formed [Kamp, 1986; Norris and Turnbull, 1993; Turnbull et al., 1993]. More recent analysis of seafloor-spreading in the southwest Pacific confirms that plate motion through New Zealand changed to dominantly strike-slip and significantly accelerated at $\sim 26 \mathrm{Ma}$ [Cande et al., 2000]. Previous analyses of the geometry of the Fiordland subduction zone have suggested that initial convergence occurred in either Early, Middle, or Late Miocene times [Davey and Smith, 1983; House et al., 2002; Lebrun et al., 2003; Walcott, 1998]. Convergence since $\sim 6$ Ma resulted in widespread tectonic uplift of Fiordland and increased transpression along the Alpine Fault in central South Island resulted in substantial topographic growth of the Southern Alps [Batt et al., 2004; Batt and Braun, 1999; Sutherland, 1996; Tippett and Kamp, 1993; Walcott, 1998].

\section{Exhumation and Uplift of Fiordland}

[8] Apart from a restricted coastal strip in the vicinity of Milford Sound, all rocks that have been analyzed thermochronometrically from Fiordland cooled through temperatures of $250-350^{\circ} \mathrm{C}$ during Cretaceous time [Gibson, 1982; Gibson et al., 1988; Kimbrough et al., 1994; Marks and Tikku, 2001; Muir et al., 1998; Nathan et al., 2000]. $\mathrm{K}$-feldspar ${ }^{40} \mathrm{Ar} /{ }^{39} \mathrm{Ar}$ and zircon fission track data from around Dusky Sound show that exposures south of the Dusky Fault cooled through temper- 


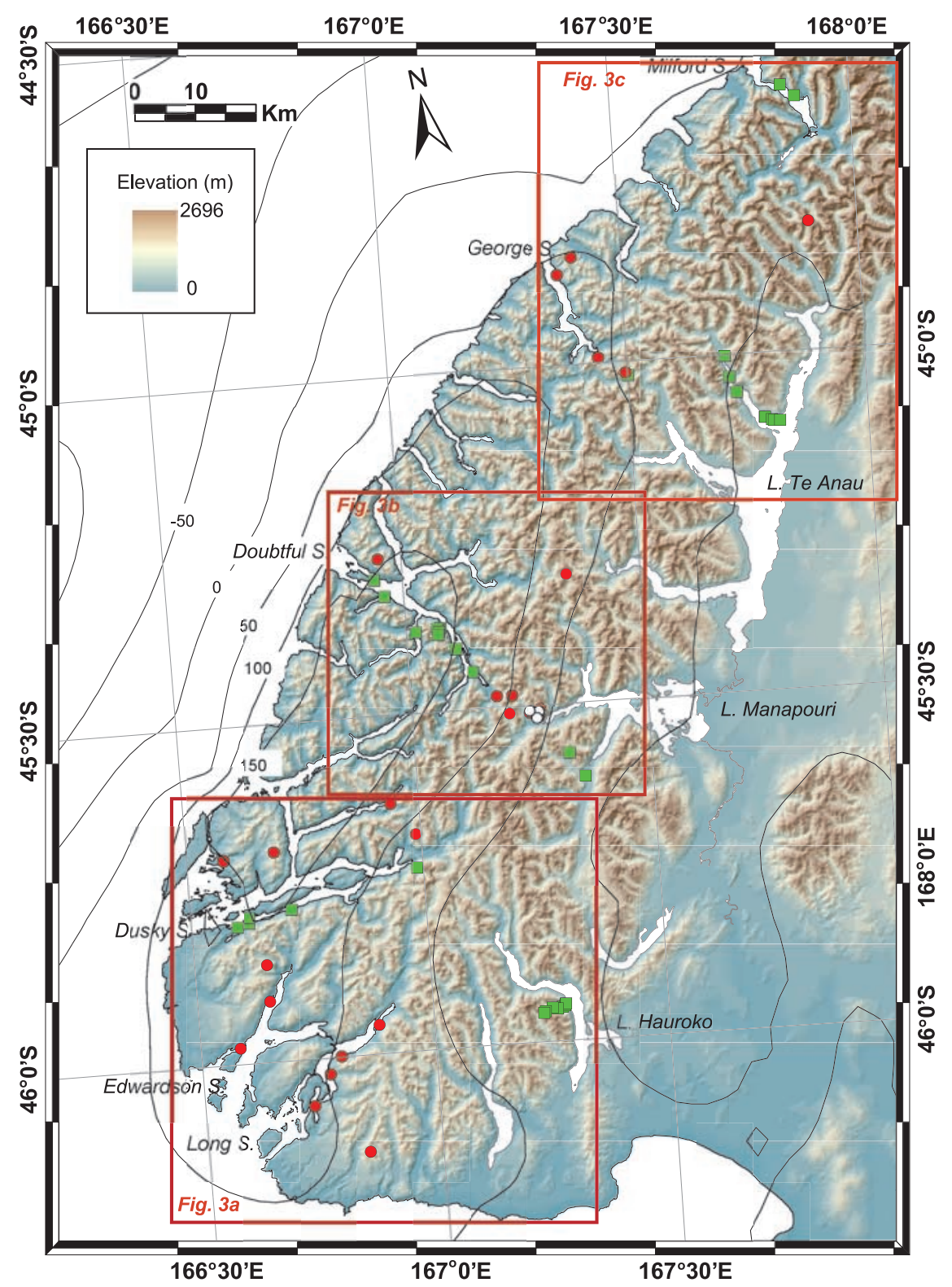

Figure 2. Location map of Fiordland showing the positions of newly dated samples (red and white circles) and samples originally reported by House et al. [2002] (green squares). White circles indicate Manapouri tunnel samples. Also shown is the Fiordland gravity anomaly (Bouguer onshore and Free-Air offshore [Davey and Smith, 1983]). The three large red boxes indicate the locations of Figures $3 a, 3 b$, and $3 c$ as labeled. Figures 2 and 3 are both shown using the New Zealand Map Grid, drawn on the New Zealand Map Grid Projection.

atures of $\sim 200^{\circ} \mathrm{C}$ during Cretaceous time while regions immediately to the north cooled much later (as late as $\sim 20 \mathrm{Ma}$ ) [Davids, 1999]. Apatite fission track and (U-Th)/He cooling ages show that the southern Dusky Sound and Hauroko regions cooled earlier and more slowly than regions to the north, although extreme ranges in cooling age are not detected using these low temperature techniques [House et al., 2002]. The apatite fission track and (U-Th)/He data indicate a distinct acceleration in exhumation in southern
Fiordland at $\sim 12 \mathrm{Ma}$, while In cooling ages in central and northern Fiordland are up to 5-7 m.y. younger. However, the spatial distribution of these ages is not sufficient to determine how the transition from older to younger ages is distributed throughout Fiordland.

\section{4. (U-Th)/He Thermochronometry}

[9] Provided that exhumation removes at least 2$3 \mathrm{~km}$ of material, then it may be detected using low 
Table 1. Apatite Ages for Fiordland Samples

\begin{tabular}{|c|c|c|c|c|c|c|c|c|c|c|c|}
\hline Sample & $\begin{array}{l}\text { Easting/ } \\
\text { Northing }\end{array}$ & El., m & $\begin{array}{l}\text { Ave. } \\
\text { Age } \\
(2 \sigma)^{\mathrm{a}}\end{array}$ & $\begin{array}{c}\text { Cor. } \\
\text { Age, } \\
\text { Ma }\end{array}$ & $\begin{array}{l}{[\mathrm{U}]} \\
\mathrm{ppm}\end{array}$ & $\begin{array}{l}{[\mathrm{Th}]} \\
\text { ppm }\end{array}$ & $\mathrm{U} / \mathrm{Th}$ & $\begin{array}{l}{\left[{ }^{4} \mathrm{He}\right],} \\
\mathrm{nmol} / \mathrm{g}\end{array}$ & $\mathrm{F}_{\mathrm{t}}$ & $\mathrm{R}, \mu \mathrm{m}$ & $\mathrm{L}, \mu \mathrm{m}$ \\
\hline \multicolumn{12}{|c|}{ George Sound and North } \\
\hline \multirow[t]{3}{*}{ МH02-03 } & E2076514/N5562358 & 1160 & $2.7(0.4)$ & 2.9 & 31.1 & 3.8 & 8.13 & 0.407 & 0.82 & 77 & 300 \\
\hline & & & & 2.7 & 36.5 & 3.8 & 9.62 & 0.461 & 0.83 & 83 & 326 \\
\hline & & & & 2.6 & 38.3 & 4.2 & 9.12 & 0.466 & 0.83 & 89 & 240 \\
\hline \multirow[t]{3}{*}{ MH02-76 } & E2072087/N5564827 & 0 & $1.9(0.3)$ & 1.9 & 75.5 & 158.7 & 0.48 & 0.911 & 0.78 & 63 & 343 \\
\hline & & & & 2.2 & 17.8 & 18.2 & 0.98 & 0.210 & 0.79 & 66 & 257 \\
\hline & & & & 1.5 & 46.8 & 92.0 & 0.51 & 0.428 & 0.75 & 54 & 257 \\
\hline \multicolumn{12}{|c|}{ Mt. Mitchelson } \\
\hline \multirow[t]{3}{*}{ MH02-33 } & E2106633/N5587489 & 1201 & $1.4(0.2)$ & 1.6 & 21.7 & 71.1 & 0.30 & 0.266 & 0.80 & 69 & 343 \\
\hline & & & & 1.4 & 8.6 & 33.4 & 0.26 & 0.100 & 0.79 & 74 & 223 \\
\hline & & & & 1.3 & 7.7 & 33.4 & 0.23 & 0.084 & 0.76 & 66 & 194 \\
\hline \multicolumn{12}{|c|}{ West George Sound } \\
\hline \multirow[t]{4}{*}{ MH02-52 } & E2067402/N5581449 & 1075 & $3.6(0.4)$ & 3.6 & 12.7 & 41.2 & 0.31 & 0.383 & 0.87 & 120 & 389 \\
\hline & & & & 3.8 & 19.1 & 71.9 & 0.27 & 0.598 & 0.80 & 69 & 377 \\
\hline & & & & 2.7 & 24.4 & 80.4 & 0.30 & 0.520 & 0.82 & 80 & 377 \\
\hline & & & & 4.1 & 20.3 & 41.6 & 0.49 & 0.542 & 0.80 & 69 & 377 \\
\hline \multirow[t]{4}{*}{ MH02-82 } & E2065210/N5578556 & 0 & $2.6(0.3)$ & 2.3 & 2.5 & 3.0 & 0.82 & 0.030 & 0.77 & 60 & 257 \\
\hline & & & & 2.1 & 4.7 & 7.4 & 0.64 & 0.060 & 0.82 & 80 & 309 \\
\hline & & & & 3.5 & 1.7 & 1.7 & 0.99 & 0.033 & 0.83 & 89 & 274 \\
\hline & & & & 2.5 & 3.3 & 3.1 & 1.06 & 0.047 & 0.84 & 91 & 317 \\
\hline \multicolumn{12}{|c|}{$\begin{array}{l}\text { Doubtful Sound } \\
\text { of Wilmot Pass } R\end{array}$} \\
\hline \multirow[t]{2}{*}{ MH02-14 } & E2066811/N5529181 & 1122 & $5.1(0.8)$ & 5.2 & 25.8 & 61.1 & 0.42 & 0.881 & 0.77 & 60 & 300 \\
\hline & & & & 5.0 & 3.8 & 2.1 & 1.81 & 0.092 & 0.78 & 74 & 154 \\
\hline \multirow[t]{2}{*}{ MH02-17 } & E2057874/N5509255 & 1414 & $5.5(0.9)$ & 4.3 & 30.6 & 2.8 & 10.79 & 0.540 & 0.74 & 51 & 208 \\
\hline & & & & 6.7 & 30.8 & 3.2 & 9.71 & 0.792 & 0.69 & 43 & 173 \\
\hline \multirow{4}{*}{ MH02-19 } & & & East-V & mot $P$ & s Regic & & & & & & \\
\hline & E2057436/N5506176 & 1188 & $3.5(0.6)$ & 3.8 & 34.2 & 1.0 & 34.68 & 0.534 & 0.74 & 51 & 240 \\
\hline & & & & 3.1 & 54.0 & 10.4 & 5.19 & 0.723 & 0.77 & 63 & 171 \\
\hline & & & & 1.2 & 0.1 & 0.1 & 0.73 & 0.001 & 0.73 & 51 & 194 \\
\hline \multirow[t]{2}{*}{ MH02-20 } & E2062074/N5506700 & 1212 & $2.6(0.4)$ & 2.9 & 4.3 & 2.8 & 1.53 & 0.054 & 0.70 & 46 & 146 \\
\hline & & & & 2.3 & 4.3 & 3.4 & 1.27 & 0.041 & 0.63 & 37 & 137 \\
\hline \multirow[t]{3}{*}{ MH02-21 } & E2062440/N5507114 & 1501 & $4.2(0.6)$ & 3.5 & 24.7 & 17.5 & 1.42 & 0.419 & 0.77 & 60 & 251 \\
\hline & & & & 4.6 & 31.9 & 9.3 & 3.44 & 0.625 & 0.73 & 51 & 189 \\
\hline & & & & 4.5 & 42.9 & 25.5 & 1.68 & 0.958 & 0.80 & 69 & 291 \\
\hline \multirow[t]{3}{*}{ MH02-22 } & E2062373/N5505909 & 850 & $2.8(0.4)$ & 2.6 & 2.1 & 0.8 & 2.73 & 0.026 & 0.81 & 80 & 229 \\
\hline & & & & 3.3 & 7.8 & 3.5 & 2.21 & 0.125 & 0.80 & 69 & 309 \\
\hline & & & & 2.6 & 7.5 & 3.7 & 2.00 & 0.093 & 0.80 & 69 & 257 \\
\hline \multirow{3}{*}{ P68345 b } & & & & apouri & Tunnel & & & & & & \\
\hline & E2055382/N5509157 & 10 & $2.8(0.5)$ & 2.7 & 57.1 & 4.6 & 12.52 & 0.618 & 0.72 & 46 & 182 \\
\hline & & & & 2.9 & 35.8 & 5.2 & 6.84 & 0.404 & 0.69 & 42 & 175 \\
\hline \multirow[t]{2}{*}{ P68686 ${ }^{\mathrm{b}}$} & E2060741/N5506344 & 10 & $1.6(0.3)$ & 1.6 & 9.6 & 16.3 & 0.59 & 0.087 & 0.73 & 52 & 191 \\
\hline & & & & 1.5 & 10.5 & 18.6 & 0.56 & 0.088 & 0.74 & 53 & 216 \\
\hline \multirow[t]{2}{*}{ P68693 ${ }^{\mathrm{b}}$} & E2060805/N5506310 & 10 & $1.6(0.3)$ & 1.6 & 91.1 & 51.1 & 1.78 & 0.632 & 0.69 & 43 & 171 \\
\hline & & & & 1.6 & 214.6 & 90.5 & 2.37 & 1.499 & 0.71 & 46 & 178 \\
\hline P68719 & E2062219/N5505568 & 10 & $1.8(0.4)$ & 1.8 & 6.0 & 7.3 & 0.83 & 0.057 & 0.75 & 56 & 212 \\
\hline & & & West & ecreta & Island & & & & & & \\
\hline MH02-56 & E2035708/N5531718 & 1211 & $4.6(0.5)$ & 3.7 & 1.0 & 0.3 & 3.15 & 0.016 & 0.75 & 54 & 223 \\
\hline & & & & 5.8 & 2.3 & 0.6 & 4.14 & 0.059 & 0.78 & 69 & 189 \\
\hline & & & & 4.6 & 3.6 & 6.3 & 0.58 & 0.099 & 0.78 & 66 & 231 \\
\hline & & & & 4.3 & 0.9 & 1.8 & 0.53 & 0.024 & 0.76 & 57 & 240 \\
\hline
\end{tabular}


Table 1. (continued)

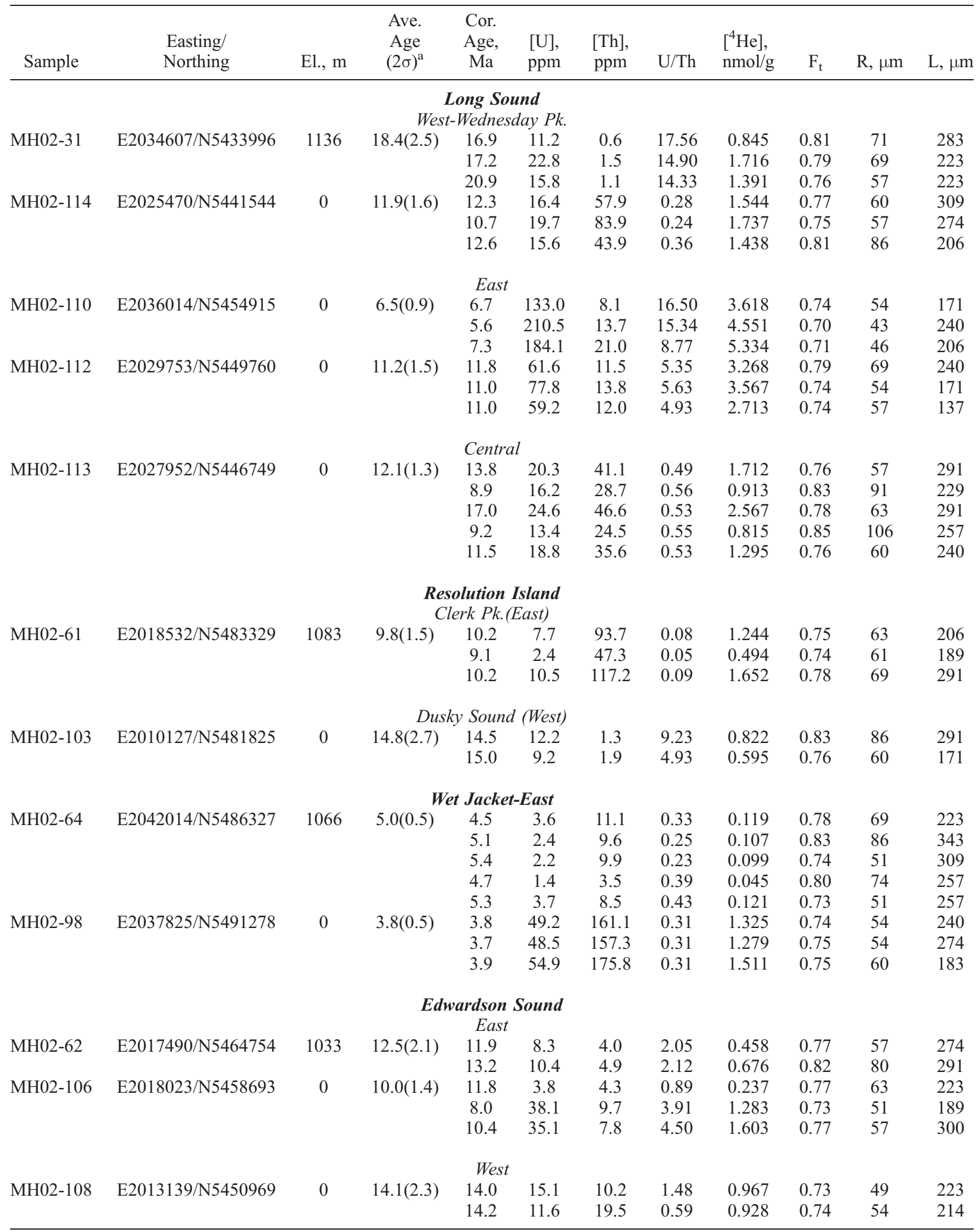


temperature thermochronometry. Given a nominal geothermal gradient in the $20-30^{\circ} \mathrm{C} / \mathrm{km}$ range and a $5^{\circ} \mathrm{C}$ surface temperature, exhumation from depths of $\sim 2-3 \mathrm{~km}$ ought to be accompanied by cooling from above temperatures $\sim 70^{\circ} \mathrm{C}$, and so should be recorded by (U-Th)/He apatite thermochronometry (AHE), a technique with a closure temperature of $\sim 70^{\circ} \mathrm{C}$ [Farley, 2000]. In actual fact, the transition between quantitative loss and retention of helium in apatite occurs over a thermal window of $\sim 40-70^{\circ} \mathrm{C}$ the helium partial retention zone, similar to the apatite fission track partial annealing zone. The (U-Th)/He closure temperature, taken to be the temperature at the base of the helium partial annealing zone, scales with apatite grain size (larger grain sizes have higher closure temperatures). Although the grain-size effect is slight (from 75-150 micron prism diameter, the closure temperature varies by just $6^{\circ} \mathrm{C}$ ) it can be used to advantage in samples with a range of grain sizes. Thus an apatite (U-Th)/He age provides an additional information on the time-temperature history of a specific sample, permitting documentation of exhumational histories from extremely shallow levels in the Earth's crust.

[10] The low temperature cooling history of a rock can be expanded more by using (U-Th)/He zircon thermochronometry (ZHE) with a closure temperature of $\sim 180 \pm 20^{\circ} \mathrm{C}$ (possibly corresponding to depths of 6-9 km given the assumptions above) [Reiners and Farley, 1999].

[11] Our sample strategy was devised to further delineate the northward decrease in cooling ages observed in our pilot study as well as to investigate whether any significant east-west variations in cooling ages exist, and how they might be accommodated. We focused on 4 general regions (Figure 2): (1) Long and Edwardson Sounds; (2) Wet Jacket Arm (including Resolution Island); (3) Doubtful Sound (including Wilmot PassSecretary Island); and (4) George Sound. Samples were collected from sea level and from elevations centered on a reference datum of $1100 \pm 100 \mathrm{~m}$ above sea level, as well as one additional sample from $\sim 1500 \mathrm{~m}$. Comparison of spatial variations in cooling ages for sea level samples should further delineate patterns of differential exhumation identified in our first study and allow us to extend this comparison into southern Fiordland. Cooling ages from the reference elevation horizon can also be compared toward the same end and can be used in combination with nearby sea level samples to evaluate first order variations in exhumation rates across the region by comparing the age-elevation relationships that result.

[12] AHE and ZHE ages were obtained at the Caltech Noble Gas Laboratory. Apatites were analyzed using methods described by House and others [House et al., 2000], while zircons were analyzed following Farley and others [Farley et al., 2002]. Analytical details and results are shown in Tables 1 and 2.

\section{Apatite (U-Th)/He Results}

\subsection{Southwest Fiordland: Long, Edwardson, and Dusky Sounds, Wet Jacket Arm}

[13] AHE ages were obtained for 6 sea level samples along Long and Edwardson Sounds/ Chalky Inlet, as well as from elevation (1136 and $1033 \mathrm{~m}$, respectively) in southwest Fiordland (Figures 2 and 3a). Sea level samples were also collected from western Resolution Island and the head of Wet Jacket Arm (samples MH02-103 and MH02-98, respectively), and at elevation from eastern Resolution Island (MH02-61, $1083 \mathrm{~m}$ ) and at the head of Wet Jacket Arm (MH02-64, $1066 \mathrm{~m})$.

[14] AHE ages for sea level samples from the heads of Wet Jacket Arm and Long Sound, respectively, are $3.8 \pm 0.5 \mathrm{Ma}$ and $6.5 \pm 0.9 \mathrm{Ma}$ (Figure 4a), while the rest of the sea level samples from this region yield older ages (from $10.0 \pm$ 1.4 $\mathrm{Ma}$ in central Edwardson Sound to $14.8 \pm$ $2.7 \mathrm{Ma}$ on western Resolution Island). Except for the significantly younger samples at the heads of

\footnotetext{
Notes to Table 1:

${ }^{a}$ Error is the 2 sigma standard error [Farley et al., 2001]: $0.117 * 2 *($ average age)/sqrt $(\mathrm{N})$, where $\mathrm{N}$ is the number of replicates and 0.117 is the average standard deviation of the entire data set. Easting and Northing refer to New Zealand map grid coordinates; elevation is with respect to sea level. $\mathrm{F}_{\mathrm{t}}$ is computed from grain size measurements (radius, R, and length, L) following the method of Farley et al. [1996]. All samples consist of single crystals and were outgassed using the Nd-YAG approach of House et al. [2000]. Each age discussed in the text is the average computed from multiple single crystal aliquots of apatite. The average grain-radius of the apatite samples analyzed is $67 \pm 14$ microns, corresponding to a closure temperature of $77^{\circ} \mathrm{C}$, assuming a linear cooling rate of $10^{\circ} \mathrm{C} / \mathrm{m} . \mathrm{y}$. [Farley et al., 1996].

${ }^{\mathrm{b}}$ Samples collected from Manapouri Tunnel. All sample locations are reported using coordinates in meters in terms of the New Zealand Geodetic Datum of 1949.
} 
Table 2. Zircon Helium Ages ${ }^{\mathrm{a}}$

\begin{tabular}{|c|c|c|c|c|c|c|c|c|c|c|c|}
\hline Sample & Subsample & $\begin{array}{c}\text { Age, } \\
\mathrm{Ma}\end{array}$ & $\begin{array}{l}{[4 \mathrm{He}],} \\
(\mathrm{nmol}) / \mathrm{g}\end{array}$ & $\begin{array}{l}{[\mathrm{U}],} \\
\mathrm{ppm}\end{array}$ & $\begin{array}{l}{[\mathrm{Th}],} \\
\text { ppm }\end{array}$ & $\mathrm{U} / \mathrm{Th}$ & $\begin{array}{c}\text { Mass, } \\
\mu \mathrm{g}\end{array}$ & $\mathrm{F}_{\mathrm{t}}$ & $\mathrm{L}, \mu \mathrm{m}$ & $\mathrm{R}, \mu \mathrm{m}$ & $\begin{array}{c}\text { Ave. Age, } \\
\text { Ma }\end{array}$ \\
\hline \multicolumn{12}{|c|}{ Long Sound } \\
\hline \multirow[t]{2}{*}{ МH02-31 } & $\mathrm{c}$ & 115.1 & 27.469 & 601.5 & 16.5 & 36.56 & 3.2 & 0.72 & 12 & 6.2 & $112.2(25.4)$ \\
\hline & d & 109.3 & 21.385 & 450.2 & 111.8 & 4.03 & 4.4 & 0.75 & 12 & 7.2 & \\
\hline \multirow[t]{3}{*}{ MH02-113 } & a & 97.4 & 19.041 & 371.2 & 186.9 & 1.99 & 31.3 & 0.86 & 31 & 12 & $89.6(16.6)$ \\
\hline & b & 83.0 & 18.047 & 407.0 & 237.4 & 1.71 & 31.3 & 0.86 & 31 & 12 & \\
\hline & $\mathrm{c}$ & 88.4 & 24.141 & 530.3 & 185.0 & 2.87 & 41.3 & 0.87 & 30 & 14 & \\
\hline \multicolumn{12}{|c|}{ Wet Jacket } \\
\hline \multirow[t]{2}{*}{ МH02-98 } & $\mathrm{a}$ & 9.62 & 0.309 & 58.1 & 40.8 & 1.42 & 41.3 & 0.87 & 30 & 14 & $13.6(3.1)$ \\
\hline & $\mathrm{c}$ & 17.5 & 0.459 & 48.2 & 40.7 & 1.18 & 26.7 & 0.84 & 38 & 10 & \\
\hline \multirow[t]{4}{*}{ МH02-64 } & $\mathrm{a}$ & 16.3 & 0.345 & 323.8 & 773.1 & 0.42 & 49.8 & 0.87 & 42 & 13 & $13.9(2.2)$ \\
\hline & $\mathrm{b}$ & 12.4 & 0.892 & 118.0 & 193.1 & 0.61 & 63.3 & 0.88 & 46 & 14 & \\
\hline & $\mathrm{c}$ & 13.1 & 0.217 & 24.8 & 47.6 & 0.52 & 13.9 & 0.81 & 27.5 & 8.5 & \\
\hline & $\mathrm{d}$ & 13.7 & 0.590 & 65.7 & 133.3 & 0.49 & 26.3 & 0.85 & 31 & 11 & \\
\hline \multicolumn{12}{|c|}{ George Sound } \\
\hline \multirow[t]{3}{*}{ MH02-03 } & $\mathrm{b}$ & 10.8 & 2.565 & 509.9 & 179.4 & 2.84 & 10.4 & 0.79 & 23.25 & 8 & $11.2(2.1)$ \\
\hline & $\mathrm{c}$ & 8.6 & 1.534 & 400.2 & 106.5 & 3.76 & 6.7 & 0.77 & 17 & 7.5 & \\
\hline & d & 14.3 & 3.100 & 452.5 & 169.8 & 2.66 & 13.1 & 0.81 & 23 & 9 & \\
\hline \multirow[t]{2}{*}{ MH02-76 } & $\mathrm{a}$ & 4.1 & 0.225 & 98.8 & 93.5 & 1.06 & 20.4 & 0.84 & 24 & 11 & $4.3(1.0)$ \\
\hline & $\mathrm{b}$ & 4.5 & 0.164 & 67.8 & 57.3 & 1.19 & 16.8 & 0.83 & 24 & 10 & \\
\hline
\end{tabular}

\footnotetext{
${ }^{\mathrm{a}}$ Sample locations are shown in Table 1 . Zircons are all euhedral and approximately equidimensional $\left(\mathrm{R}_{\mathrm{a}} \approx \mathrm{R}_{\mathrm{b}}\right)$. $\mathrm{F}_{\mathrm{t}}$ correction computed following Farley et al. [1996]. All samples consist of single crystals and were outgassed using the Nd-YAG approach of House et al. [2000] and were dissolved for U-Th analysis using the method of Farley et al. [2002].

${ }^{\mathrm{b}}$ Error is the 2 sigma standard error computed following the method of Farley et al. [2001]: $0.32 * 2 *($ average age)/sqrt $(\mathrm{N})$, where $\mathrm{N}$ is the number of replicates and 0.32 is the average standard deviation of the entire data set. Each age discussed in the text is the average computed from multiple single crystal aliquots of zircon. All sample locations are reported using coordinates in meters in terms of the New Zealand Geodetic Datum of 1949 .
}

Wet Jacket and Long Sound, there is no systematic relationship between cooling age and position along any of the sounds.

[15] AHE cooling ages from the $\sim 1100 \mathrm{~m}$ samples are generally older than adjacent sea level samples and show the same jump to younger ages at the eastern limit of Wet Jacket Arm: the AHE age of MH02-64 at the head of Wet Jacket Arm is $5.0 \pm$ $0.5 \mathrm{Ma}$, while ages to the southwest are considerably older (MH02-31 is $18.4 \pm 2.5 \mathrm{Ma}$ and $\mathrm{MH02}-62$ is $12.5 \pm 2.1 \mathrm{Ma}$ ). One sample (MH02-61, from eastern Resolution Island) is younger than the closest sea level sample $(9.8 \pm$ $1.5 \mathrm{Ma})$, however.

\subsection{Central Fiordland: Wilmot Pass to Outer Doubtful Sound}

[16] Eleven new samples from the Doubtful Sound region (nine from the Wilmot Pass region including the Manapouri Tunnel, one from Secretary Island, and one from Fowler Pass to the north) were analyzed (Figures 2 and $3 b$ ). The new AHE ages from central Fiordland are similar in range to those from Doubtful Sound originally reported by House et al. [2002]. Samples from the Wilmot Pass area adjacent to the head of Doubtful Sound range in elevation from 10-1501 m (including several from within a tunnel at the edge of Lake Manapouri, Table 1) and generally exhibit a positive correlation with elevation (ranging from $1.0 \pm 0.5 \mathrm{Ma}$ to $4.2 \pm$ $0.6 \mathrm{Ma})$. A single sample from Secretary Island (MH02-56, $1211 \mathrm{~m}$ ) yielded an age of $4.6 \pm 0.5 \mathrm{Ma}$. This sample is $\sim 1$ m.y. older than the age observed at a similar elevation at Wilmot Pass. Samples from the north and east of the head of Doubtful Sound (MH02-14, $1122 \mathrm{~m}$ and MH02-17, $1414 \mathrm{~m}$ ) are older still $(5.1 \pm 0.8 \mathrm{Ma}$ and $5.5 \pm 0.9 \mathrm{Ma}$, respectively) than samples from comparable elevations to the west (Figure 4b).

\subsection{Northern Fiordland: George Sound Region}

[17] Five samples were analyzed from the George Sound region (Figures 2 and 3c): two at sea level (MH02-76 at the head of the sound in the east and MH02-82 at the mouth to the west), two at elevation (MH02-3 from $1160 \mathrm{~m}$ at the head and MH02-52 from $1075 \mathrm{~m}$ from the mouth of the sound), and one additional sample located to 

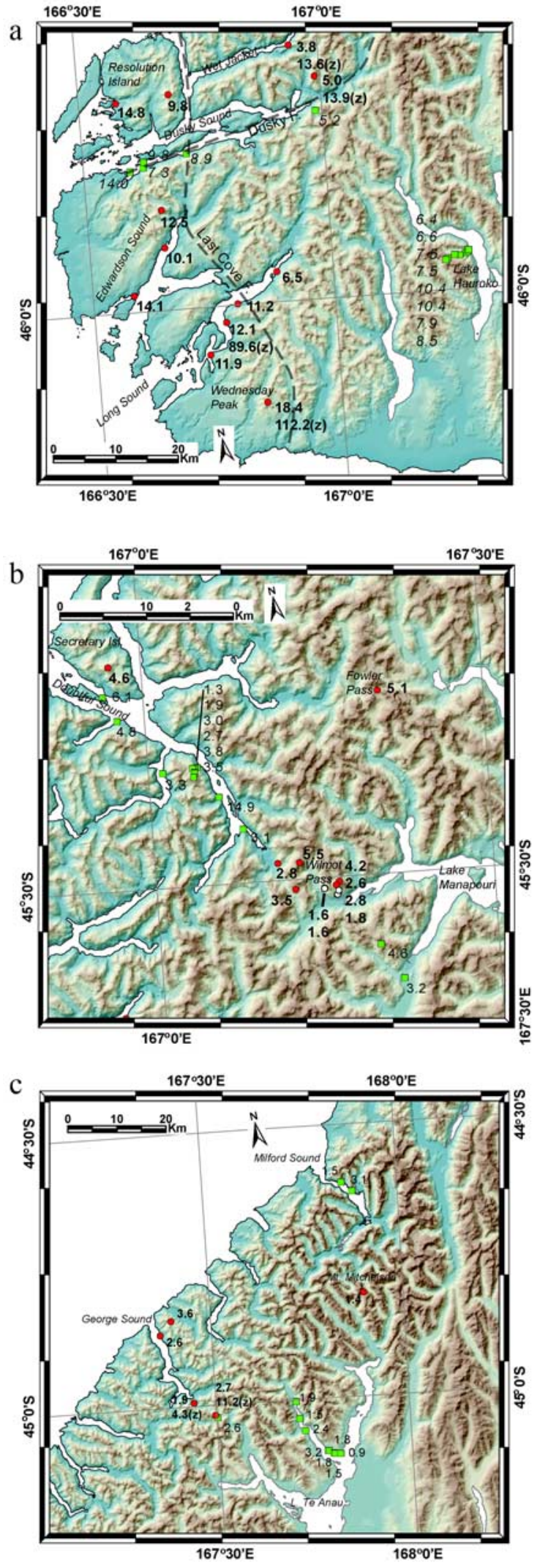

the north of George Sound from $\sim 1100 \mathrm{~m}$ elevation (MH02-33). The AHE ages from the sea level samples are 1.9 and $2.6 \mathrm{Ma}$, while adjacent high elevation samples are consistently older (2.7 and 3.6 Ma, respectively). In addition, the ages of both sea level and $\sim 1100 \mathrm{~m}$ samples at the mouth of the sound are all roughly $1 \mathrm{Ma}$ older than samples at similar elevations farther to the east (Figure 4c). Sample MH02-33 to the north is considerably younger than the other samples $(1.4 \pm 0.2 \mathrm{Ma})$.

\section{Zircon Results}

[18] Zircons from a subset of samples were analyzed in order to constrain a portion of the higher temperature cooling history of Fiordland. Samples were selected in order to obtain ages from a range of elevations in locations across central and southern Fiordland, including the head of Wet Jacket Arm (MH02-64 and MH02-98), along Long Sound (MH02-113 and MH02-31) and at the head of George Sound (MH02-03 and MH02-76). For each site, samples from sea level and nearby at $\sim 1100 \mathrm{~m}$ elevation were selected for analysis (Table 2).

[19] In general, the ZHE cooling ages from southern Fiordland are significantly older than those from the north (Figure 5). At Long Sound, ZHE ages range from $89.6 \mathrm{Ma}$ at sea level to $\sim 112.2 \mathrm{Ma}$ at $1136 \mathrm{~m}$, while they are significantly younger at George Sound and Wet Jacket Arm. For example, a single sea level sample from George Sound is 4.3 Ma compared to $11.2 \mathrm{Ma}$ at $1160 \mathrm{~m}$. Ages from the head of Wet Jacket Arm are also young: compare 13.6 Ma at sea level to $13.9 \mathrm{Ma}$ at $1066 \mathrm{~m}$ (Figures 3 and 5).

\section{Discussion}

[20] AHE ages from upper Wet Jacket Arm, George Sound, and the Doubtful Sound region

Figure 3. Maps of sample areas: (a) southwestern Fiordland, (b) central Fiordland, and (c) northern Fiordland. Newly dated samples are shown with red and white circles (white are for the Manapouri tunnel samples), and those originally reported by House et al. [2002] are shown by green squares. New AHE ages (indicated by bold text) and ZHE ages (indicated by bold text with age followed by "z") are shown. Ages of House et al. [2002] are shown with regular text. 

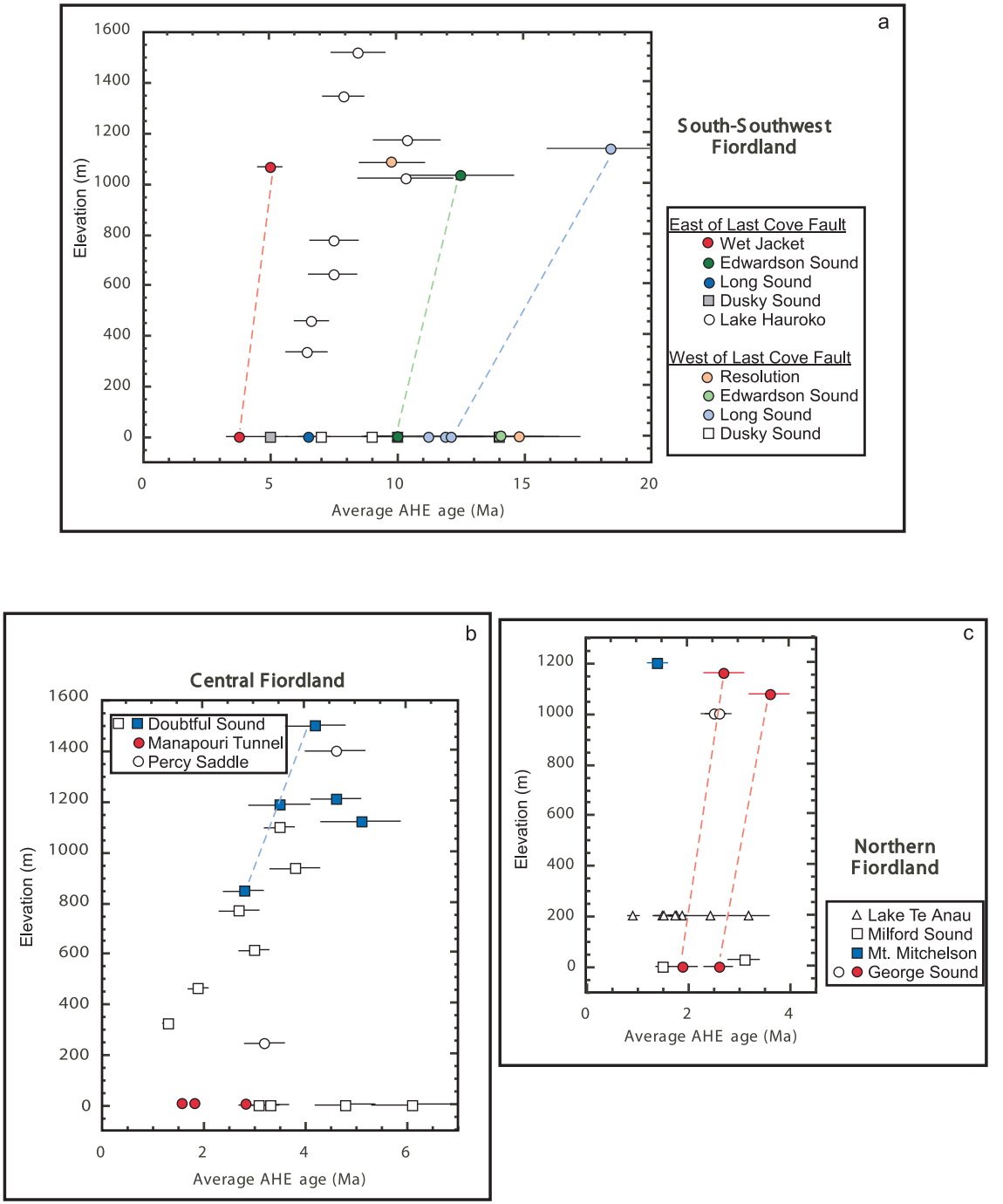

Figure 4. Apatite helium age results from Fiordland. New results are plotted together with results from House et al. [2002]. Data from House et al. [2002] are shown with open or gray symbols. Dashed lines connect samples that are collected from the same vicinity (for example, a sea level sample and the nearest sample from the $\sim 1100 \mathrm{~m}$ reference elevation). Plotted ages are average values computed from replicate analyses shown in Table 1. Errors are 2 sigma standard errors computed following Farley et al. [2001] (see description in the Table 1 footnotes). (a) Ages from south-southwest Fiordland. Data from east of the Last Cove Fault are shown with dark filled circles, while those from the west of the Last Cove Fault are shown with light filled circles. Data of House et al. [2002] from Lake Hauroko (open circles) and Dusky Sound (squares) are shown in gray and open symbols, corresponding to locations east and west of the Last Cove Fault, respectively. (b) Ages from Central Fiordland transects with data of House et al. [2002] from Doubtful Sound (open squares) and Percy Saddle (open circles). (c) Ages from northern Fiordland transects, including George Sound and Mount Mitchelson (filled circles and squares, respectively), and data of House et al. [2002] for Lake Te Anau (open triangles) and the George Sound (open circles) and Milford Sound area (open squares).

are consistent with previously reported results [House et al., 2002] showing a similar trend toward younger cooling ages in the north. The data indicate that cooling from temperatures of $>77^{\circ} \mathrm{C}$ (presumably related to exhumation from depths of 2-3 km) has occurred since $\sim 5 \mathrm{Ma}$ in central Fiordland (Wet Jacket and Wilmot), but is slightly younger to the north $(\sim 3-2 \mathrm{Ma}$ at George Sound). Sea level AHE ages show that southwest Fiordland, which had not been previously studied, cooled through the AHE closure isotherm roughly $10-8$ m.y. earlier than northern and central Fiordland, respectively (Figure 4). 


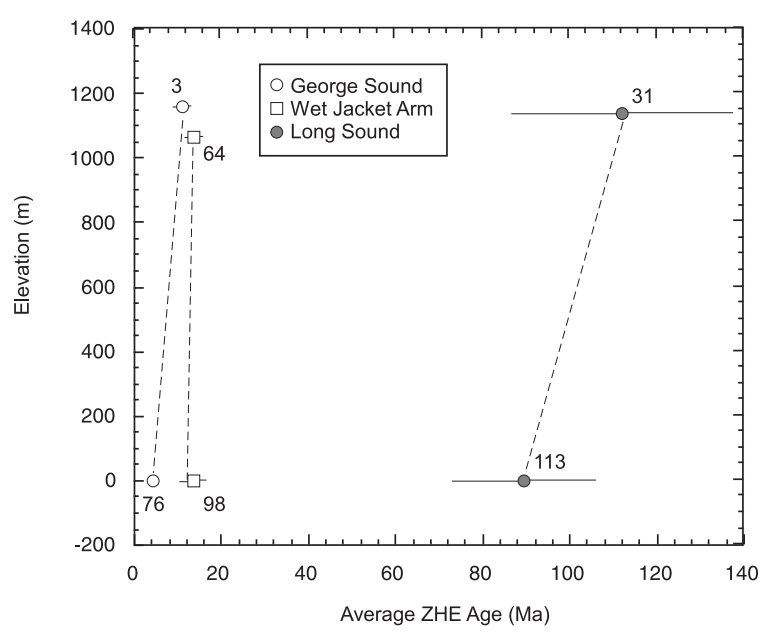

Figure 5. Zircon helium age results from George Sound, Wet Jacket Arm, and Long Sound. All ages shown are average values computed from individual replicates shown in Table 2; errors are 2 sigma. Dashed lines connect samples that are adjacent to one another in the field.

[21] In addition to the general southward increase in AHE ages across Fiordland, there is a slight east to west variation in AHE ages apparent at several locations. Comparison of cooling ages from sea level and at $\sim 1100 \mathrm{~m}$ in George Sound and at Doubtful Sound shows that cooling ages to the west are slightly older than those to the east in both locations (Figure 4). In both areas, the exhumation rates are similar as indicated by the age-elevation relationships, but relative ages differ by $\sim 1$ m.y.

[22] Preservation of older AHE ages to the south has been interpreted to reflect the northward migration of a locus of bedrock uplift and exhumation related to subduction initiation [House et al., 2002]. However, these age patterns may also reflect differential uplift that produced significantly different amounts of exhumation that are responsible for the range of cooling ages that we observe. For example, slightly older AHE ages in western Fiordland relative to those in the east may reflect increased bedrock uplift (and resulting exhumation) by faults that parallel the coast, so that deeper crustal levels with younger ages are exposed to the east, while concurrent (but less pronounced) bedrock uplift and exhumation to the west preserved older ages in rocks that were exhumed from shallower crustal levels. Brittle faults are widespread in Fiordland and although no individual fault need have a very large throw, the net result may be significant. For example, if these coast parallel faults acted as west-vergent reverse faults, as would be expected in the overriding plate above an active subduction zone, they would produce age patterns like those observed.

[23] The case for fault-related differential uplift and exhumation is stronger in southwestern Fiordland, where AHE ages show discontinuities across at least one major structure. The spatially localized shift (1-5 m.y.) in ages from sea level samples within Long and Edwardson Sounds appears to correspond to the position of the Last Cove fault (Figure 1). This structure, which bounds the Kakapo granite on the east and extends northward along the Acheron Passage (Figure 1 and Figure 2), clearly defines a major basement terrain boundary.

[24] AHE and AFT ages that span the Dusky fault increase gradually from north to south across this region, no obvious break in low-temperature cooling ages is apparent in the data near the fault. However, higher temperature cooling ages from the region (K-feldspar ${ }^{40} \mathrm{Ar} /{ }^{39} \mathrm{Ar}$ and ZFT) reveal a significant jump to younger ages in the north, not only across Dusky Sound, but also across Wet Jacket Arm [Davids, 1999]. These patterns of ages suggest that faults underlying both Dusky Sound and Wet Jacket arm may have accommodated significant offsets prior to Miocene times, but have largely been inactive or have accommodated only minimal offset since. More information is needed to determine the magnitude of this offset however.

[25] Cooling ages from eastern Dusky and Long Sounds and Wet Jacket Arm are similar at a given elevation to those from Lake Hauroko, which lies within the median Tectonic zone to the east (Figure 1). This similarity in ages among samples from the Southwestern Fiordland block, the Central Belt and the Median Tectonic zone suggests that outside of the region south-southwest of the Last Cove fault, regional variations in exhumation across the rest of Fiordland are largely gradational and cannot be correlated to any particular faults at present. Nevertheless, as mentioned above, as yet unrecognized structures may play a role in the pattern of cooling ages that we observe in the region.

\section{Conclusion}

[26] Our data show that at least some of the uplift of Fiordland, SW New Zealand, is accommodated by faulting within the plate. In particular, available 
mapping and our AHE ages indicate that the exhumation history southwest of the Last Cove fault may be partially decoupled from that to the north and east. Elsewhere, we conclude that differential exhumation across individual faults within Fiordland is unresolvable using our data.

[27] The general pattern of our new AHE and ZHE cooling ages from Fiordland confirm and expand on previous results. New data from southwest Fiordland agree with our earlier hypothesis that rapid exhumation in southern Fiordland initiated at $\sim 12 \mathrm{Ma}$ [House et al., 2002]. Younger cooling ages in the north may reflect either the northward migration of the locus of onset of uplift and exhumation related to subduction initiation, or the onset of exhumation may have been synchronous, but with greater exhumation rates in the north. These alternative hypotheses can only be resolved through analysis of a larger data set that includes systems with a range of closure temperatures. In light of this conclusion, further data collection, analysis and modeling are underway to resolve the geodynamic hypotheses that this data set has allowed us to form.

\section{Acknowledgments}

[28] This work was supported by NSF grant EAR-0003558 to House and Gurnis. We thank Lindsey Hedges at Caltech for assistance in apatite and zircon dating. JoAnne Giberson at Caltech was invaluable in constructing our basemaps.

\section{References}

Barnes, P. M., R. Sutherland, B. Davy, and J. Delteil (2001), Rapid creation and destruction of sedimentary basins on mature strike-slip faults: An example from the offshore Alpine Fault, New Zealand, J. Struct. Geol., 23, 1727-1739.

Batt, G. E., and J. Braun (1999), The tectonic evolution of the Southern Alps, New Zealand: Insights from fully thermally coupled dynamical modelling, Geophys. J. Int., 136, 403420.

Batt, G. E., S. L. Baldwin, M. A. Cottam, P. G. Fitzgerald, M. T. Brandon, and T. L. Spell (2004), Cenozoic plate boundary evolution in the South Island of New Zealand: New thermochronological constraints, Tectonics, 23, TC4001, doi:10.1029/2003TC001527.

Bradshaw, J. Y. (1989), Origin and metamorphic history of an Early Cretaceous polybaric granulite terrain, Fiordland, southwest New Zealand, Contrib. Mineral. Petrol., 103(3), $346-360$.

Bradshaw, J. Y. (1990), Geology of crystalline rocks of northern Fiordland: Details of the granulite facies western Fiordland orthogneiss and associated rock units, N.Z.J. Geol. Geophys., 33(3), 465-484.

Cande, S. C., J. M. Stock, R. D. Mueller, and T. Ishihara (2000), Cenozoic motion between East and West Antarctica, Nature, 404(6774), 145-150.
Clarke, G. L., K. A. Klepeis, and N. R. Daczko (2000), Cretaceous high-P granulites at Milford Sound, New Zealand: Metamorphic history and emplacement in a convergent margin setting, J. Metamorph. Geol., 18(4), 359-374.

Cooper, R. A. (1989), Early Paleozoic terranes of New Zealand, J.R. Soc. N.Z., 19(1), 73-112.

Daczko, N. R., K. A. Klepeis, and G. L. Clarke (2001), Evidence of Early Cretaceous collisional-style orogenesis in northern Fiordland, New Zealand and its effects on the evolution of the lower crust, J. Struct. Geol., 23(4), 693713.

Davey, F. J., and E. G. C. Smith (1983), The tectonic setting of the Fiordland region, south-west New Zealand, Geophys. J.R. Astron. Soc., 72, 23-38.

Davids, C. (1999), A thermochronological study of southern Fiordland, New Zealand, Ph.D. thesis, 232 pp., Aust. Natl. Univ., Caberra.

Eberhart-Phillips, D., and M. Reyners (2001), A complex, young subduction zone imaged by three-dimensional seismic velocity, Fiordland, New Zealand, Geophys. J. Int., 146(3), $731-746$.

Farley, K. A. (2000), Helium diffusion from apatite: General behavior as illustrated by Durango fluorapatite, J. Geophys. Res., 105(B2), 2903-2914.

Farley, K. A., et al. (1996), The effects of long alpha-stopping distances on (U-Th)/He dates, Geochim. Cosmochim. Acta, 60, 4223-4230.

Farley, K. A., M. E. Rusmore, and S. W. Bogue (2001), Post$10 \mathrm{Ma}$ uplift and exhumation of the northern Coast Mountains, British Columbia, Geology, 29, 99-102.

Farley, K. A., B. P. Kohn, and B. Pillans (2002), The effects of secular disequilibrium on (U-Th)/he systematics and dating of Quaternary volcanic zircon and apatite, Earth Planet. Sci. Lett., 201, 117-125.

Gibson, G. M. (1982), Polyphase deformation and its relation to metamorphic crystallisation in rocks at Wilmot Pass, central Fiordland, N.Z.J. Geol. Geophys., 25(1), 45-65.

Gibson, G. M., I. McDougall, and T. R. Ireland (1988), Age constraints on metamorphism and the development of a metamorphic core complex in Fiordland, southern New Zealand: Reply, Geology, 17(4), 381-382.

House, M. A., K. A. Farley, and D. Stockli (2000), Helium chronometry of apatite and titanite using Nd-YAG laser heating, Earth Planet. Sci. Lett., 183, 365-368.

House, M. A., M. Gurnis, P. J. J. Kamp, and M. R. Sutherland (2002), Timing of recent uplift in the Fiordland region of New Zealand: Implications for incipient subduction, Science, 297, 2038-2041.

Kamp, P. J. J. (1986), Late Cretaceous-Cenozoic tectonic development of the southwest Pacific region, Tectonophysics, $121,225-251$.

Kimbrough, D. L., A. J. Tulloch, D. S. Coombs, C. A. Landis, M. R. Johnston, and J. M. Mattinson (1994), Uranium-lead zircon ages from the Median Tectonic Zone, South Island, New Zealand, N.Z.J. Geol. Geophys., 37(4), 393-419.

Lebrun, J., G. Lamarche, and J. Collot (2003), Subduction initiation at a strike-slip plate boundary: The Cenozoic Pacific-Australian plate boundary, south of New Zealand, J. Geophys. Res., 108(B9), 2453, doi:10.1029/ 2002JB002041.

Marks, K. M., and A. A. Tikku (2001), Cretaceous reconstructions of East Antarctica, Africa and Madagascar, Earth Planet. Sci. Lett., 186(3-4), 479-495.

Mortimer, N., A. J. Tulloch, R. N. Spark, N. W. Walker, E. Ladley, A. Allibone, and D. L. Kimbrough (1999), Overview of the Median Batholith, New Zealand: A new 
interpretation of the geology of the Median Tectonic Zone and adjacent rocks, J. Afr. Earth Sci., 29(1), 257-268.

Muir, R. J., T. R. Ireland, S. D. Weaver, J. D. Bradshaw, J. A. Evans, G. N. Eby, and D. Shelley (1998), Geochronology and geochemistry of a Mesozoic magmatic arc system, Fiordland, New Zealand, J. Geol. Soc. London, 155(6), 1037-1053.

Nathan, S., C. Thurlow, P. Warnes, and R. Zucchetto (2000), Geochronology Database for New Zealand Rocks (2nd Edition), 1961-1999, Sci. Rep. 2000/11, pp. 1-51, Inst. of Geol. and Nucl. Sci., Lower Hutt, New Zealand.

Norris, R. J., and I. M. Turnbull (1993), Cenozoic basins adjacent to an evolving transform plate boundary, southwest New Zealand, in South Pacific Sedimentary Basins, Sedimentary Basins of the World, vol. 2, edited by P. F. Ballance, pp. 251-270, Elsevier, New York.

Norris, R. J., R. M. Carter, and I. M. Turnbull (1978), Cainozoic sedimentation in basins adjacent to a major continental transform boundary in southern New Zealand, J. Geol. Soc. London, 135, 191-205.

Oliver, G. J. H., and J. H. Coggon (1979), Crustal Structure of Fiordland, New Zealand, Elsevier, New York.

Reiners, P. W., and K. A. Farley (1999), Helium diffusion and (U-Th)/He thermochronometry of titanite, Geochim. Cosmochim. Acta, 63, 3845-3859.

Sutherland, R. (1996), Transpressional development of the Australia-Pacific boundary through southern South Island, New Zealand: Constraints from Miocene-Pliocene sedi- ments, Waiho-1 borehole, South Westland, N.Z.J. Geol. Geophys., 39(2), 251-264.

Tippett, J. M., and P. J. J. Kamp (1993), Fission track analysis of the Late Cenozoic vertical kinematics of continental Pacific crust, South Island, New Zealand, J. Geophys. Res., 98, 16,119-16,148.

Toth, J., and M. Gurnis (1998), Dynamics of subduction initiation at preexisting fault zones, J. Geophys. Res., 103(B8), $18,053-18,068$.

Tulloch, A. J. (1983), Granitoid rocks of New Zealand: A brief review, in Circum-Pacific Plutonic Terranes, edited by J. A. Roddick, Mem. Geol. Soc. of Am., 159, 5-20.

Turnbull, I. M., and C. I. Uruski (1995), Geology of the Monowai-Waitutu area, map, Inst. of Geol. and Nucl. Sci., Lower Hutt, New Zealand.

Turnbull, I. M., et al. (1993), Cretaceous and Cenozoic Sedimentary Basins of Western Southland, South Island, New Zealand, vol. 1, 86 pp., Inst. of Geol. and Nucl. Sci., Lower Hutt, New Zealand.

Walcott, R. I. (1998), Modes of oblique compression: Late Cenozoic tectonics of the South Island of New Zealand, Rev. Geophys., 36(1), 1-26.

Ward, C. M. (1984), Geology of the Dusky Sound region Fiordland, Ph.D. thesis, Univ. of Otago, Dunedin, New Zealand.

Wood, R. A., G. Lamarche, R. H. Herzer, J. Delteil, and B. Davy (1996), Paleogene seafloor spreading in the southeast Tasman Sea, Tectonics, 15, 966-975. 